\title{
A BIZALOM SZEREPE EGY FELSŐOKTATÁSI REFORM MEGVALÓSULÁSÁBAN: A FENNTARTÓI MEGÁLLAPODÁSOK ESETE
}

A cikk a magyar felsőoktatásban 2008 és 2010 között működő hároméves fenntartói megállapodás bevezetését és működését vizsgálja. Az állami felsőoktatási intézmények 2017-ben három évre vonatkozó megállapodást kötöttek az Oktatási és Kulturális Minisztériummal, amelynek keretében stabil finanszírozásért cserébe indikátorok teljesítését vállalták. A tanulmány fő kérdése, hogy az intézmények vajon miért írtak alá olyan megállapodást, amely jelentős kockázatokkal járt rájuk nézve, és amelyek bekövetkezése valószínűsíthető volt. A kérdés megválaszolása a bizalommal foglalkozó szakirodalom segítségével történik, amelynek során a minisztérium megbízhatóságának, azaz hozzáértésének, jóakaratának és integritásának értékelésére kerül sor. ${ }^{1}$

Kulcsszavak: bizalom, felsőoktatás, teljesítménymegállapodás, szerződés

A tanulmány alapkérdése, hogy vajon hogyan befolyásolja a közpolitikai kezdeményezések implementációját, illetve annak sikerességét a folyamatban részt vevő szereplők egymás iránti bizalma.

Noha a bizalom társadalmi szerepének vizsgálata igen régre nyúlik vissza (például megtalálható olyan filozófusok, politikai gondolkodók és társadalomtudósok írásaiban, mint Hobbs, Locke, Simmel, Durkheim vagy Parsons), a bizalommal kapcsolatos érdeklődés az 1980as évektől kezdett el jelentősen növekedni olyan társadalomfilozófusok írásai nyomán, mint például Giddens, Luhmann és Beck. A fogalmat később felfedezte magának a közgazdaságtudomány (például Williamson, 1993), a szervezetkutatás, a politikatudomány (Putnam, Hardin, Fukuyama) és a szociológia, továbbá a jog, a kriminalisztika, a pszichológia és a közmenedzsment is.

A bizalom elötérbe kerülése minden bizonnyal viszszavezethető a társadalmi változásokra: a növekvő munkamegosztás, a hálózatosodás, a technológiai fejlődés és a globalizáció mind a társadalom komplexitásának és a környezet bizonytalanságának növekedésével járnak, ami miatt egyre gyakrabban vagyunk kénytelenek ügyeinket olyanokra bízni, akiket személyesen nem ismerünk, vagy akiknek szakértelme az adott területen meghaladja a miénket. A bizalom nemcsak a társas viszonyok komplexitását csökkentik kezelhető mértéküre (hiszen így nem kell minden szereplő minden lehetséges magatartását mérlegelni), hanem fontos összetevőjét jelentik a kooperációnak is, ami - a munka természetének átalakulása miatt - a kérdést az üzleti világ, s így a menedzsmentkutatás számára is érdekessé teszi.

A közszférában a bizalom kérdése az ún. ügynökségek elterjedése (lásd van Thiel, 2012) miatt vált különösen aktuálissá az elmúlt másfél évtizedben. Az ügynökség olyan fél-autonóm közszervezet, amely a kormányzattól „karnyújtásnyira" működik (Verhoest, 2018)². Ügynökségnek tekinthetök mindazok a szervezetek, amelyek ugyan minisztériumi felügyelet alatt müködnek, de attól szervezetileg elkülönülnek és kisebb-nagyobb önállósággal (autonómiával) bírnak. Például ügynökségek az olyan szabályozó hatóságok mint a NAV, vagy az olyan közszolgáltatásokat nyújtó szervezetek, mint például a kórházak vagy az egyetemek. Noha a magyarországi gyakorlatban nem jellemző, hogy e szervezetekről ügynökségként beszéljünk (sem a közszférában, sem a közszférakutatásban), az ügynökségek számának növekedése Magyarországon is érvényes trend volt a 2000-es évek elején (Hajnal, 2012).

Természetesen félig autonóm szervezetek korábban is léteztek, elterjedésük azonban az utóbbi évtizedekben vált széles körüvé. Ez szorosan összefügg az 1980-as években elsősorban az angolszász, később a nyugat-európai országokban teret nyert mozgalommal, az Új Közmenedzsmenttel (New Public Management; NPM) (Osborne - Hutchinson, 2012). A mozgalmat a jóléti szolgáltatások iránti folyamatosan emelkedő igények váltották ki. Az 1970-es évektől az igények kielégítése a költségvetési korlátok és a hirtelen megugró energiaárak miatt nem volt már lehetséges. Az NPM erre kínált megoldást elsősorban a hatékonyság fokozásával, az üzleti életben bevett irányítási technikák alkalmazásával és a piaci viszonyok erőteljesebb érvényesítésével. Ennek egyik fontos eleme a közszféra decentralizálása volt.

A decentralizált modellben a kormányzat elsősorban a közpolitikák tervezésével, a szolgáltatás nyújtásának felügyeletével foglalkozik. A közpolitikák implementálása és a szolgáltatások nyújtása már az ügynökségek feladata, amelyek szabadságot (autonómiát) kapnak a célok elérési módjának megválasztásában és a belső források alloká-

\footnotetext{
Köszönetnyilvánítás:

A cikk a Bolyai János Kutatási Ösztöndíj program keretében készült. Ezúton is szeretnék köszönetet mondani a Magyar Tudományos Akadémiának a támogatásért. Emellett szeretnék köszönetet mondani a cikk két anonim bírálójának a hasznos észrevételekért és megjegyzésekért.

${ }^{2}$ Másik elnevezésük a quango, azaz quasi-autonomous non governmental organizations.
} 
ciójában. A szolgáltatások nyújtásába a közszervezetek mellett a magánszervezetek is bekapcsolódhatnak, így a kormányzat elvben versenyeztetheti a potenciális szolgáltatókat, ezáltal is lejjebb szorítva az szolgáltatások költségvetési forrásigényét. A hatósági jellegű tevékenységek esetében pedig az ügynökségek önállóbbá válása ahhoz vezet, hogy azok kevésbé lesznek átpolitizáltak, és kevésbé vannak kitéve a napi politikai küzdelmeknek, ezáltal szakszerübben tudják ellátni feladatukat.

A különböző fokú autonómiával rendelkező ügynökségek, illetve egy-egy ágazat egészének kormányzati irányítása új felügyeleti eszközök bevezetését igényelte (Verhoest et al., 2012). Ezek közé tartoznak például a kimenetre irányuló eszközök, így a teljesítményszerződések is. E fejlemények vezettek az ún. autonómia-paradoxonhoz, amely szerint az autonómia növekedése a kontroll növekedését is eredményezi (Rommel \& Christaens, 2009).

Mindezek a folyamatok jól tetten érhetők a felsőoktatás területén is, ahol az egyetemek régóta müködnek szervezeti önállósággal, de karnyújtásnyira a kormányzattól. $\mathrm{Az}$ intézmények autonómiája és a felügyeletük elfogadható módjai folyamatosan témái mind a magyar, mind a nemzetközi sajtónak.

A következőkben a magyar felsőoktatásban 2007ben bevezetett hároméves fenntartói megállapodások rendszerét vizsgálom meg a bizalom nézőpontjából. E megállapodások megfeleltethetők a nemzetközi gyakorlatban teljesítménymegállapodásoknak (performance agreement/contract) nevezett eszköznek, amelyek az elmúlt évtizedben váltak szélesebb körben elterjedtté. Magyarországon ezen irányítási eszköz bevezetésére viszonylag korai időszakban került sor. Ennek tapasztalatai ugyanakkor Magyarországon reflektálatlanok, nemzetközileg pedig ismeretlenek maradtak. Ebből a szempontból ezért érdekes lehet még egy évtized távlatából is visszatekinteni erre a kísérletre, és elemezni a müködésének dinamikáját. Ennek talán apropót ad az is, hogy bár 2011 után a direkt felügyeleti és kontrolleszközök váltak dominánssá az intézmények ágazati irányításában (például intézményi vezetők - kancellár, költségvetési felügyelö, belső ellenőr - minisztériumi kinevezése, minisztériumtól függő felügyelő testületek, finanszírozási rendszer átalakulása stb.), a teljesítményelvü felsőoktatás hosszabb távon megítélésem szerint nem képzelhető el az intézmények érdekeltté tétele, az autonómiájuk és mozgásterük bővítése nélkül, amihez másféle, talán a teljesítményszerződésekhez hasonló logikák bevezetése lesz szükséges.

Az elemzéshez először röviden bemutatom azokat a trendeket, amelyek a külföldi felsőoktatási rendszerekben a teljesítménymegállapodások bevezetését eredményezték. Ezt követően áttekintem a teljesítménymegállapodások legfontosabb jellemzőit, sikertényezőit. Ezt követően vázolom fel a szereplök közötti bizalmat leíró analitikus modellt, amely szempontokat ad a fenntartói megállapodások dinamikájának elemzéséhez. A magyarországi kontextus ismertetése után rátérek a hároméves fenntartói megállapodások bevezetésének folyamatára, a kutatási dilemma ismertetésére és a szereplők magatartásának elemzésre. A tanulmányt következtetésekkel zárom.

\section{A felsőoktatás átalakulása}

Az európai felsőoktatási rendszerek jelentős expanzión mentek keresztül az 1980-as éveket követően. Ennek következtében jelentős mértékben nőtt a felsőoktatási rendszerek komplexitása (pl. új intézménytípusok és új fenntartók jelentek meg, összetettebbé vált a képzési struktúra, heterogénebbek lettek a hallgatói igények stb.), ami miatt egyre nehezebbé vált az intézmények közvetlen kormányzati irányítása (government). A kormányzat (minisztérium) feladata egyre inkább az összetett, sokszereplős hálózat átfogó, stratégiai irányítása (governance) lett (de Boer et al., 2010), azaz a hangsúly a különböző ágazati szereplők megfelelö együttmüködését elősegítő környezet kialakulásának támogatására és a felsőoktatási tevékenység monitorozásának megszervezésére, felügyeletére és társadalmi elfogadtatására helyeződött át. Ez többnyire és összességében az intézmények autonómiájának erősödésével járt együtt elsősorban az akadémiai autonómia, és kisebb mértékben a szervezeti, a pénzügyi és humánerőforrás-autonómia területén, bár egyes országokban ettől eltérő trendek is érvényesülhettek (Pruvot \& Estermann, 2017; Estermann et al., 2011; Estermann \& Nokkala, 2009). Az intézmények egyre nagyobb szabadságot élveznek belső struktúrájuk alakításában, de általánosan elterjedtté vált a külső érintetek bevonása az újonnan létrehozott, pénzügyi és stratégiai döntéshozó testületekbe (boardokba). Az elmúlt évtizedekben számos országban (például Angliában, Finnországban, Németország több tartományában, Ausztriában) megszünt a közalkalmazotti státuszban történő foglalkoztatás kényszere, a pénzügyi válság következtében viszont az autonómia átmenetileg csökkent a bérek és a létszámok meghatározásának tekintetében (pl. Írországban).

Az intézmények pénzügyi autonómiája a finanszírozási rendszerek átalakulásával együtt változott. A hallgatói létszámok növekedése a felsőoktatás forrásigényének növekedését eredményezte, ami az állami források mellett más források (pl. tandíj, „harmadik utas” források) bevonását tette szükségessé. Így az intézmények finanszírozása egyre inkább többcsatornássá vált. Mindezek ellenére az állami források jelentősége továbbra is meghatározó, ezért ezek elosztásának mechanizmusa fontos kérdés maradt. E téren lényeges változás, hogy az állami források elosztásában általánosan elterjedtté vált a képlet szerinti finanszírozás, amelyben egyre nagyobb arányban jelentek meg az outputmutatók: míg 1995-ben mindössze öt országban alkalmaztak outputmutatókat Európában, addig ez a szám 2008-ra 19-re nőtt (Jongbloed et al., 2010). Ugyanakkor az outputmutatók által allokált források aránya bár jelentős, összességében nem meghatározó; az inputmutatók (pl. a hallgatók létszáma) továbbra is döntő (Fielden, 2008).

Egy másik jellemző változási irány, hogy az állami források elosztása maga is többcsatornássá válik, pl. az oktatás és kutatás finanszírozása gyakran teljesen eltérő csatornákon és mechanizmusokon keresztül történik. A pénzügyi autonómia szempontjából lényeges változás az átalánytámogatások (block grants) elterjedése, ami azt jelenti, hogy a támogatások nem korlátozottan átcsoportosítható költségtípusokra (bérre stb.) vagy tevékenységekre 
vonatkoznak, hanem az intézmény saját döntése alapján használhatók fel. A felsőoktatást is érintő pénzügyi-gazdasági válság következtében ugyanakkor növekedett a célzottabb feladat vagy projektfinanszírozás aránya és jelentősége (Halász, 2012; Kováts et al., 2012). Végezetül fontos megemlíteni, hogy témánk szempontjából lényeges változás a teljesítményszerződések elterjedése is. (Ezt részletesebben később mutatom be.)

Összességében megállapítható, hogy a finanszírozási rendszerben bekövetkező változások nagy része erősítette az intézmények autonómiáját, hiszen növekedett az intézmények lehetősége a bevételi csatornáiknak meghatározásában, a belső forrásallokációban, és ez sok helyen kiegészült még a tartalékképzés, a hitelfelvétel, a megtakarítások pénzügyi befektetésének és a vállalkozások alapításának lehetőségével. Korlátok elsősorban a tandíjak nagyságának meghatározásában érvényesültek.

Az intézményi autonómia növekedését a kormányzat kontrolleszközeinek sokrétübbé válása kísérte. Számos új kontrolleszköz jelent meg (Fielden, 2008; Keczer, 2016). Ezek közé tartozik például a már említett külső szereplőket is tartalmazó, az intézmények stratégiai-pénzügyi felügyeletét ellátó testületek (boardok) létrehozása, az akkreditációs és minőségellenőrzési rendszerek megjelenése, a rendszeres beszámolási és adatszolgáltatási rendszerek kiépítése, a teljesítményfinanszírozás és a feladatfinanszírozás formáinak bevezetése, az átláthatóság erősítése, a vezetők rendszeres értékelése. A kontrolleszközök sorába illeszkedik a teljesítménymegállapodások rendszere is.

\section{A teljesítménymegállapodások és a teljesítményszerződések megjelenése}

Az elmúlt időszak jellemző trendjének tekinthető a teljesitménymegállapodások (performance agreement) elterjedése is. A megállapodás ölthet szerződéses formát is, ez esetben teljesítményszerződésről beszélhetünk (performance contract). A teljesítménymegállapodások az egyes intézmények és az állam között jönnek létre, és rögzítik az adott intézmény által egy adott időszakban elérendő célokat, a célok elérését mérő indikátorokat és ezek peremfeltételeit. A megállapodások gyakran több évet ölelnek fel, ez javítja a felsőoktatási intézmények tervezési időhorizontját (az intézmények állami támogatását sok országban évente döntik/döntötték el). Tartalmazhatnak pénzügyi következményeket is: például a szerződés kitérhet az intézménynek juttatott támogatás nagyságára, valamint a célok (nem) teljesülésével járó esetleges jutalmakra, szankciókra.

Egy 11 nyugati ország gyakorlatát áttekintő összehasonlító elemzés szerint (de Boer et al., 2015; Jongbloed et al., 2018) hat országban 2010 után vezették be a teljesítménymegállapodások valamely formáját, négy országban pedig 2000 és 2007 között.

De Boer et al. (2015) számos célt említ, amely a teljesítménymegállapodásokkal elérhető:

1. az intézményi profil meghatározásának és felülvizsgálatának támogatása, amely révén egy kellően sokszínű felsőoktatási rendszer alakítható ki,

2. az intézmény és a kormányzat között olyan rendsze- res, strukturált megbeszélés kereteit adják, amely során egyértelmüsíthetők az intézménnyel szembeni elvárások, és érvényesíthetők a szakpolitikai célok,

3. képes figyelembe venni, hogy az intézmény sokféle célt követ egyidejüleg,

4. erősíti a felsőoktatás transzparenciáját és elszámoltathatóságát a kormányzat és a tágabb közvélemény elött (különösen, ha a megállapodások és a beszámolók nyilvánosak),

5. erősíti a felsőoktatás eredményességét és hatékonyságát,

6. javítja a felsőoktatási intézmények egymással való együttmüködését.

Ezen előnyök érvényesüléséhez megfelelően kialakított teljesítménymegállapodás-rendszerre van szükség (de Boer et al., 2015). Melyek a legfontosabb sikerkritériumok?

A célok mérésére olyan indikátorokat kell választani, amelyek érvényesek, megbízhatóak és relevánsak. Fontos mérlegelni azt is, hogy a teljesítménymegállapodások milyen kapcsolatban (esetlegesen átfedésben) vannak más finanszírozási vagy tervezési eszközökkel. A teljesítménymegállapodások hatásosságához szükséges az átfogó ágazati célrendszer vagy stratégia léte, ami az intézmények számára is támpontul szolgálhat. Ilyen célrendszer nélkül a teljesítménymegállapodások gyakorlata öncélú lesz.

Dönteni kell, hogy a megállapodásokhoz kapcsolódnak-e pénzügyi ösztönzők. Általános tapasztalat, hogy minden fél komolyabban veszi a megállapodásokat, ha vannak pénzügyi következmények. Célszerü, hogy ezek ne csak az alulteljesítés szankcióit tartalmazzák, hanem térjenek ki a túlteljesítés esetére is. A pénzügyi ösztönzők nagyságát úgy kell megválasztani, hogy az valóban ösztönző legyen, de ne legyen túlzó méretü, ellenkező esetben nem kívánt ösztönzési hatások léphetnek fel. Például ha a lemorzsolódás csökkentése a cél, és ehhez jelentős pénzügyi forrás társul, akkor annak lehet következménye, hogy az intézmények szigoríthatják a bejutási feltételeket csökkentve ezáltal a felsőoktatáshoz való hozzáférés lehetőségét. De járhat a végzés feltételeinek könnyítésével is, ami minőségrontó hatású lehet.

A pénzügyi ösztönzők forrása lehet a már meglévő költségvetés, vagy lehet többletforrás is. Az utóbbit könynyebb az intézményekkel elfogadtatni (pl. a rendszer bevezetés esetén), de válság esetén ezek a források könnyebben áldozatul esnek a megszorításoknak.

Fontos kérdés, hogy a megállapodások/szerződések mennyire tekinthetők kötelező érvényünek a felekre nézve: inkább csak szándéknyilatkozatok, vagy valódi szerződések, amelyek akár bíróságon is kikényszeríthetők? További kérdés - különösen a több évet felölelő szerződések esetén -, hogy mi a teendő alulteljesítés vagy nemteljesítés esetén. Gyakori a szerződés közös módosítása, a támogatások csökkentése vagy visszafizetése (akár a következő időszak támogatásából), egyes privilégiumok megvonása vagy az autonómia szintjének változtatása (de Boer et al., 2015).

Lényeges kérdés a szerződések és teljesítések transzparenciája is, amely erősíti a felek hajlandóságát a megállapodások szerinti teljesítésre, és erősíti az ellenőrizhetőséget is. 
A teljesítménymegállapodások rendszerének „üzemeltetése", a szerződések végigtárgyalása, monitorozása, kiértékelése rendkívül erőforrás-igényes feladat, amely sajátos szakértelmet, kompetenciát is igényel (de Boer et al., 2015). A szerződések kidolgozásába, monitorozásába érdemes lehet külső érintetteket is bevonni.

De Boer et al. (2015) külön kitér arra, hogy a megfelelö teljesítménymegállapodásokhoz szükséges az, hogy a miniszter a többi kormányzati szereplő támogatását is bírja a tárgyalások során, hogy a szerződések folytonossága biztosítható legyen.

Mint minden szerződés vagy megállapodás esetében, úgy itt is lényeges szerepet játszik a bizalom. Vajon menynyire bízhat az egyik fél abban, hogy a másik fél teljesíteni fog? Hogy nem törekszik a feltételek kijátszására? Mennyi biztosítékot célszerủ beépíteni a szabályozásba vagy magába a szerződésébe, illetve a szerződés megvalósulásának ellenőrzésébe? A következőkben röviden bemutatom a bizalom egy lehetséges értelmezését, azt az elemzési keretet, amelyet a magyarországi hároméves fenntartói megállapodások elemzéséhez fogok használni.

\section{A teljesítményszerződések elemzésének elméleti kerete}

A bizalom alatt - Rousseau et al. (1998) definíciója alapján - azt a pszichológiai állapotot értem, amikor a bizalmat adó hajlandó sebezhetőnek lenni a bizalmat kapóval szembeni pozitív várakozások alapján. Ez a definíció a bizalmat nem egy szereplő attitüdjeként definiálja (ez az ún. általánosított bizalom lenne), hanem azt két szereplő közötti viszony jellemzőjeként írja le. Emellett azt is feltételezi, hogy a bizalmat adónak van valamilyen célja, aminek nem teljesülése sérelmet okoz számára, azaz a bizalom szoros kapcsolatban áll a kockázatvállalási hajlandósággal. A cél teljesülése igényli a bizalmat kapó fél közreműködését. Aki bizalommal van, az úgy véli, hogy a bizalmat kapó fél a bizonytalan környezet ellenére megfelel majd ezeknek az elvárásoknak, és nem fog visszaélni a helyzettel, nem fogja azt opportunista módon kihasználni.

A bizalom elemzésének egyik leggyakrabban használt keretét Mayer és társai (1995) által megfogalmazott modell jelenti, amelyet később több publikációban is értelmeztek, kiegészítettek és pontosítottak (Schoorman et al., 2007; 2015) (1. ábra).

1. ábra A bizalom egy modellje

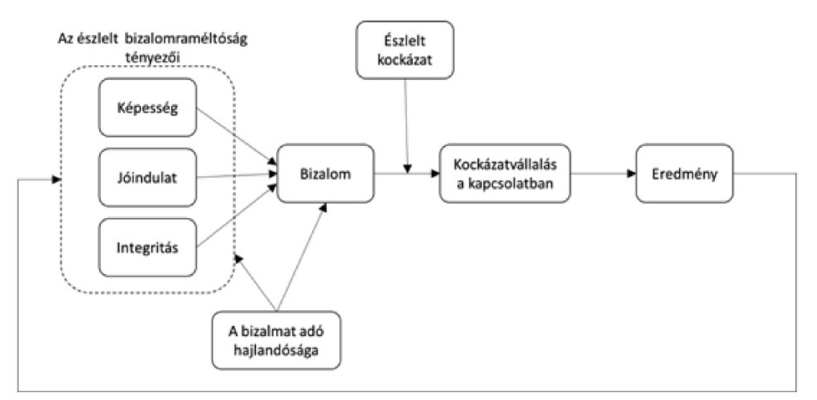

Forrás: Mayer et al. (1995)
Mayerék úgy vélik, hogy több tényezőtől függ az, hogy a bizalmat adó fél mikor hajlandó vállalni a sebezhetőséget. E tényezők közé tartozik:

- az illető hajlandósága, általánosított bizalma (propensity to trust), azaz arra vonatkozó feltételezés (várakozás), hogy egy adott közösség bármely tagja egy szituációban adott módon, egymáshoz hasonlóan fog-e viselkedni (például visszaadja-e vagy nem az utcán talált pénztárcát) (Tóth, 2010). Ez a tényező véleményem szerint megfeleltethető a szakirodalomban található általánosított bizalom fogalmával (generalized trust).

- a másik fél bizalomra méltóságának (trustworthiness) észlelése, amely függ

o a bizalmat kapó szereplő képességének megítélésétől (ability), azaz attól, hogy az érintett a bizalmat adó szempontjából fontos tevékenységet várhatóan milyen szakértelemmel, hozzáértéssel végzi el,

o a bizalmat kapó szereplő jóindulatának megítélésétől (benevolence), azaz hogy a bizalmat kapó a döntései során várhatóan milyen mértékben veszi figyelembe a bizalmat adó céljait, érdekeit,

o a bizalmat kapó szereplő integritásának megítélésétől (integrity), azaz attól, hogy a bizalmat kapó értékrendje, normái mennyire elfogadhatóak a bizalmat adó számára.

- az kockázat észlelt nagyságától.

Megkülönböztethetjük tehát a bizalmat adó fél jellemzőit, a bizalmat kapó fél jellemzőit és a szituáció jellemzőit. A későbbiekben számos más modell is átvette a tényezők ilyen vagy ehhez hasonló csoportosítását, és néhány újabb tényezőt is felvetettek. Hurley (2012) például figyelembe veszi a bizalmat adó fél kockázatvállalási hajlandóságát, a szereplők közötti hatalmi különbségeket, a szereplők közötti (társadalmi) hasonlóságot, az érdekek illeszkedését vagy ütközését.

A bizalomra vonatkozó döntést követően szerzett tapasztalatok fényében újraértékelhető a másik fél bizalomraméltósága és a szituáció egyes jellemzői, ami alapján a döntés fenntartható vagy megváltoztatható. A bizalomra vonatkozó döntést tehát a szituáció megváltozása is okozhatja.

Sok szerző (pl. Rommel \& Christaens, 2009; Lewicki \& Bunker, 1998) igyekszik megkülönböztetni a bizalom különböző típusait: ezek közé tartozik például a kalkulatív bizalom, az identifikáción és a tudáson alapuló bizalom, valamint a folyamatalapú bizalom. Az ún. kalkulatív (vagy mérlegelésen, érdeken alapuló) bizalom azon alapszik, hogy a másik félnek mikor (nem) éri meg opportunista módon viselkednie. ${ }^{3}$ Ez alapján tehát olyan helyzeteket érdemes előállítani, amikor a másik félnek nem éri meg az „árulás”. Ez a „bizalom” tehát lényegében az elrettentésen alapszik, ami miatt egyesek nem is igazán tekintik ezt valódi bizalomnak, mert hiányzik belőle a másik félbe vetett hit („leap of faith”, ahogy Möllering (2001) fogalmaz). Az azonosuláson (identifikáción) alapuló bizalom alapja a hasonló szocializáció és értékvilág a két fél között, míg

${ }^{3}$ Lásd még erről Hardin encapsulated interest elméletét (Hardin, 2006). 
a tudásalapú bizalom a másik megismeréséből, viselkedésének kiszámíthatóságából fakad (Lewicki \& Bunker, 1996). ${ }^{4}$ A folyamatalapú bizalom (process based trust) pedig lényegében a bizalom rekurzív jellegét hangsúlyozza.

Bármelyik modellt vagy kategorizálást is nézzük, fontos kihangsúlyozni, hogy a bizalomra méltóság szempontjából kritikus a kommunikáció szerepe. Minthogy a bizalom(ra méltóság) alapvetően társas konstrukciós folyamatokban alakul ki, ezért a kommunikáció gyakorisága és nyíltsága bizalomhoz, míg a gyenge kommunikáció bizalmatlansági spirálhoz vezethet. A kommunikáció ritkulása, kiüresedése akkor is könnyen bizalmatlansághoz vezethet, ha egyébként más tényezők nem változnak.

Noha Mayer et al. (1995) modellje alapvetően a szervezeten belüli viszonyok elemzését célozta meg, a felvetett szempontok a szervezetek közötti viszonyok, így a Minisztérium és az intézmények közötti viszonyok elemzésére is használhatóak.

A következőkben e modell segítségével szeretném elemezni a magyar felsőoktatásba bevezetett hároméves fenntartói megállapodások rendszerét és müködését. A vizsgálat célja nem a fenti bizalom-modell empirikus tesztelése, hanem a szituáció elemzése a modellből fakadó szempontok segítségével.

\section{A magyar felsőoktatás átalakulása és a teljesítményszerződések bevezetése}

A magyar felsőoktatás átalakulása a 2010-es évekig nagyjából követte a korábban bemutatott nemzetközi trendeket. A rendszerváltást követően megkezdődött a hallgatói létszámok növekedése, aminek eredményeképpen a hallgatók száma 1990 és 2005 között 102 ezer föről 380 ezer före nött. Ezt követően azonban a létszámok csökkenni kezdtek és 2010-ben már csak 318 ezer fő tanult a felsőoktatásban.

A rendszerváltást követően kiteljesedett az 1980-as években megkezdődött ágazati és intézményirányítási reform, amely az 1993-as törvénnyel, illetve annak 1996os módosításával csúcsosodott ki (Derényi, 2009). Ennek révén az intézmények akadémiai autonómiája jelentősen emelkedett a korábbi évtizedhez képest, de a következő években fokozatosan növekedett az intézmények szervezeti, pénzügyi és személyzeti autonómiája is. Ezt az időszakot meghatározta a humboldti modell eszménye, amely az intézményeknek akadémiai területen jelentős önirányítást, a működtetés területén viszont erős állami folyamatszabályozást és egyben piaci védettséget is biztosított. Mindez jól tükröződött például abban, hogy az intézmények szabadon állapíthatták meg a tandíjak nagyságát, belső szervezeti struktúrájukat egyre szabadabban alakíthatták (pl. karok alapításának szabadsága), az oktatók és vezető oktatók kiválasztásában szintén szabad kezet kaptak, ugyanakkor az intézmények továbbra is költségvetési intézmények maradtak annak minden államháztartási korlátjával együtt.
A 2000-es években induló újabb reformfolyamatok az intézményi autonómia növelése mellett újféle állami kontrolleszközök bevezetésére is irányultak. Tovább növekedett az intézmények gazdálkodási szabadsága (például a 2005-ös felsőoktatási törvény révén), ugyanakkor a kormányzat sikeresen kényszerítette ki az intézmények integrációját és a kétciklusú képzési struktúra bevezetését, versengővé alakította az államilag finanszírozott alapszakos hallgatók elosztási mechanizmusát, és kísérletet tett a külső érintetteket is képviselö, stratégiai és pénzügyi kérdésekben döntési jogosítványnyal rendelkező irányító testületek (boardok) bevezetésére (Barakonyi, 2009). Ez utóbbi törekvés az Alkotmánybíróság döntése alapján meghiúsult (hogy aztán később a konzisztóriumok formájában szülessen újjá) (Kováts et al., 2017).

Ebbe a trendbe illeszkedik az ún. hároméves fenntartói megállapodások bevezetése is. Ennek ötlete 2006 végén, 2007 elején merült fel az akkoriban bevezetett osztrák minta alapján. A konstrukció részleteinek kidolgozása viszonylag gyorsan történt: 2007 tavaszán a Magyar Rektori Konferencia már véleményezhette a koncepció első változatát, majd 2007 júniusában került sor a felsőoktatási törvény módosítására. A törvénymódosításhoz füzött indokolás szerint a változtatás célja, hogy „növekedjen a - megújuláshoz, a jelentős változtatásokhoz nélkülözhetetlen - finanszírozási biztonság, a kiszámíthatóság, ugyanakkor a megállapodásokban is rögzített, az intézmények által meghatározott teljesítményvállalások értékelése alapján az intézmények ösztönzést kapjanak tevékenységük eredményes alakításához." A törvénymódosítás azt is tartalmazta, hogy 2010-re a felsőoktatás állami támogatása 214 milliárd forintról 241 milliárdra fog nőni, és ezzel megőrzi reálértékét. A koncepció második körös véleményezésére októberben, a szerződések véglegesítésére novemberben került sor. A szerződéseket az Oktatási és Kulturális Minisztérium (OKM, a továbbiakban: Minisztérium) és az intézmények képviselői 2007 decemberében írták alá ünnepélyes keretek között.

A megkötött szerződésekben egyfelöl rögzítették azokat az indikátorokat és azok célértékét az elkövetkező három évre, amelyek teljesítését az adott intézmény vállalta. A fenntartói megállapodás első változatában az intézményeknek a Minisztérium által meghatározott indikátorok közül kellett volna meghatározott számút választania. A tényleges szerződésbe viszont már olyan indikátorok kerültek be, amelyeket az intézmények maguk határoztak meg, a minisztériumi “étlap”-on szereplő indikátorok csak ajánlások voltak. Az intézmények 12-23 közötti számú mutatót határoztak meg. Szintén az intézmények jelölték ki az egyes indikátorok éves célértékeit is. Az egyedüli megkötés az volt, hogy az intézményeknek minden fontosabb területen (így a képzésben, a kutatásban, a gazdálkodásban, az irányításban és a másokkal való együttmüködésben) kellett indikátorokat választaniuk, amelyeknek kapcsolódniuk kellett a már korábban (2006-ban) jóváha-

\footnotetext{
${ }^{4}$ Az előrejelezhetőség nem azonos a bizalommal. Ha valakiről tudom, hogy az érdekeim ellenében fog cselekedni, az ugyan kiszámítható, de mégsem fogok bízni benne, azaz vállalni az ezzel járó kockázatot (lásd Mayer et al., 1995).
} 
gyott intézményfejlesztési tervekhez (IFT). A választott indikátorokat és célértékeket a Minisztérium hagyta jóvá, de ezekről már csak az idő rövidsége miatt sem volt érdemi megbeszélés az intézményekkel.

A szerződés másik része az intézményeknek rendszeresen járó támogatás nagyságát részletezte. Ehhez az intézményeknek járó állami támogatást két részre bontották. A szerződésben garantált ún. alaptámogatás a fenntartói támogatást, a beruházásokkal összefüggő szolgáltatásvásárláshoz (PPP-programok) biztosított kormányzati hozzájárulást, valamint a normatívákhoz nem köthető intézményi feladattámogatást foglalta magában. Az évenként változó támogatás pedig minden más normatívát és tételt magában foglalt ('igy a hallgatói, a képzési és a tudományos normatívát). 2007-ben az alaptámogatás aránya a teljes állami támogatásokon belül igen nagy, átlagosan $27 \%$ volt $^{5}$. Az arány az intézmények többségében 20-25\% körül mozgott, de volt néhány intézmény, ahol ettől jelentős eltérés volt: az egyik nagy intézményben ennek aránya alig 13\% volt, egy müvészeti intézményben viszont meghaladta a $60 \%$-ot is.

A szerződésben rögzítették, hogy az intézményeknek az elöre haladásról évente kellett beszámolót benyújtaniuk a Minisztériumnak. A célok módosítására közös megegyezéssel volt lehetőség. Az alaptámogatás nagysága nem kötődött közvetlenül az egyes indikátorértékek teljesítéséhez vagy a kitüzött célok eléréséhez. A szerződések azt tartalmazták, hogy a céloktól való jelentős elmaradás esetén a Minisztérium jogosult az intézmény átalakulását (pl. összevonását) kezdeményezni vagy a támogatás egy részét megvonni. A szerződés jelentős elmaradásként definiálta azt, ha az intézmény a (saját maga által) kitüzött célok egyharmadát nem éri el. Jelentős elmaradást jelen- tett az is, ha - a szerződés sablonszövege szerint - ,az Intézmény a jóváhagyott maximális hallgatói létszámához képest a beiratkozott, és bejelentkezett összhallgatóinak a száma két egymást követő évben csökken, és a csökkenés mértéke valamelyik évben meghaladja a 10 százalékot."

Ez utóbbi feltételt az intézmények a fenntartói megállapodás előzetes véleményezése során kifejezetten sérelmezték. A Magyar Rektori Konferencia által 2007. november 19-én küldött véleménye szerint bizonytalan a „jóváhagyott maximális hallgatói létszám” értelmezése. Felhívják arra a figyelmet, hogy „,a jóváhagyott maximális létszámot túllépni (növelni) nem lehet. Így az intézmények vagy elérik a maximális hallgatói létszámot, vagy az ehhez viszonyított beiratkozott hallgatói létszám csökkenését állapíthatják meg évente. Az, hogy ez, egymást követő években is bekövetkezik, erősen valószínűsíthető." A vélemény mindezt a demográfiai hullámvölggyel indokolja.

Összességében tehát a szerződésbe foglalt fenntartói megállapodások igen komoly kockázatokat jelenthettek az intézményekre nézve, amennyiben a Minisztérium a szerződéseket komolyan veszi, hiszen a valószínüleg bekövetkező kedvezőtlen esetben a támogatásuk jelentős részét vagy az önállóságukat is elveszíthetik.

Ha az intézményvezetők megnézték a szerződéskötés előtti évek hallgatói létszámváltozásának alakulását, akkor a szerződéstervezetnek riadalmat kellett kiváltania. Ezt igazolta az is, hogy a hallgatói létszámok az intézmények többségénél csökkentek, és több vidéki intézményben (EJF, KE, NYF, SZF) a csökkenés mértéke nemcsak a szerződéskötés előtti időszakban, hanem azt követően, több évben is meghaladta a 10\%-ot (1. táblázat).

Noha a törvény a megállapodások megkötését kötele-

1. táblázat A hallgatói létszámok változása 2006 és 2010 között az állami felsőoktatási intézményekben

\begin{tabular}{|c|c|c|c|c|c|c|c|c|c|}
\hline \multirow{2}{*}{ Intézmény megnevezése } & \multicolumn{5}{|c|}{ Hallgatók száma összesen } & \multicolumn{4}{|c|}{ Hallgatók számának változása } \\
\hline & 2006 & 2007 & 2008 & 2009 & 2010 & $2006->2007$ & 2007->2008 & 2008->2009 & $2009->2010$ \\
\hline Berzsenyi Dániel Főiskola & 5869 & 4941 & - & - & - & $-15,8 \%$ & - & - & - \\
\hline Budapesti Corvinus Egyetem & 17879 & 17708 & 18031 & 17422 & 17134 & $-1,0 \%$ & $1,8 \%$ & $-3,4 \%$ & $-1,7 \%$ \\
\hline Budapesti Gazdasági Főiskola & 18391 & 17796 & 17369 & 17911 & 17595 & $-3,2 \%$ & $-2,4 \%$ & $3,1 \%$ & $-1,8 \%$ \\
\hline $\begin{array}{l}\text { Budapesti Müszaki és Gazdaságtudo- } \\
\text { mányi Egyetem }\end{array}$ & 24009 & 22936 & 23068 & 23219 & 23655 & $-4,5 \%$ & $0,6 \%$ & $0,7 \%$ & $1,9 \%$ \\
\hline Budapesti Müszaki Főiskola & 12485 & 12110 & 11435 & 11438 & 11870 & $-3,0 \%$ & $-5,6 \%$ & $0,0 \%$ & $3,8 \%$ \\
\hline Debreceni Egyetem & 29381 & 29121 & 30418 & 30728 & 31160 & $-0,9 \%$ & $4,5 \%$ & $1,0 \%$ & $1,4 \%$ \\
\hline Dunaújvárosi Főiskola & 5042 & 4942 & 4700 & 4312 & 4085 & $-2,0 \%$ & $-4,9 \%$ & $-8,3 \%$ & $-5,3 \%$ \\
\hline Eötvös József Főiskola & 2409 & 2141 & 1868 & 1634 & 1425 & $-11,1 \%$ & $-12,8 \%$ & $-12,5 \%$ & $-12,8 \%$ \\
\hline Eötvös Loránd Tudományegyetem & 31884 & 31369 & 30378 & 30767 & 30455 & $-1,6 \%$ & $-3,2 \%$ & $1,3 \%$ & $-1,0 \%$ \\
\hline Eszterházy Károly Főiskola & 9337 & 9365 & 8602 & 8320 & 8109 & $0,3 \%$ & $-8,1 \%$ & $-3,3 \%$ & $-2,5 \%$ \\
\hline Kaposvári Egyetem & 4800 & 4049 & 3511 & 3244 & 2985 & $-15,6 \%$ & $-13,3 \%$ & $-7,6 \%$ & $-8,0 \%$ \\
\hline Károly Róbert Főiskola & 16644 & 15629 & 13380 & 11530 & 9966 & $-6,1 \%$ & $-14,4 \%$ & $-13,8 \%$ & $-13,6 \%$ \\
\hline Kecskeméti Főiskola & 5410 & 5098 & 4819 & 4917 & 4633 & $-5,8 \%$ & $-5,5 \%$ & $2,0 \%$ & $-5,8 \%$ \\
\hline Liszt Ferenc Zeneművészeti Egyetem & 843 & 826 & 809 & 809 & 744 & $-2,0 \%$ & $-2,1 \%$ & $0,0 \%$ & $-8,0 \%$ \\
\hline Magyar Képzőművészeti Egyetem & 659 & 618 & 637 & 645 & 688 & $-6,2 \%$ & $3,1 \%$ & $1,3 \%$ & $6,7 \%$ \\
\hline Magyar Táncművészeti Főiskola & 756 & 677 & 532 & 522 & 554 & $-10,4 \%$ & $-21,4 \%$ & $-1,9 \%$ & $6,1 \%$ \\
\hline Miskolci Egyetem & 14555 & 13796 & 13602 & 13940 & 13546 & $-5,2 \%$ & $-1,4 \%$ & $2,5 \%$ & $-2,8 \%$ \\
\hline Moholy-Nagy Művészeti Egyetem & 808 & 851 & 894 & 875 & 869 & $5,3 \%$ & $5,1 \%$ & $-2,1 \%$ & $-0,7 \%$ \\
\hline Nyíregyházi Főiskola & 12933 & 11675 & 10088 & 8900 & 7807 & $-9,7 \%$ & $-13,6 \%$ & $-11,8 \%$ & $-12,3 \%$ \\
\hline Nyugat-Magyarországi Egyetem & 13149 & 12097 & $15458 *$ & 14261 & 13590 & $-8,0 \%$ & $27,8 \%$ & $-7,7 \%$ & $-4,7 \%$ \\
\hline
\end{tabular}

\footnotetext{
${ }^{5}$ Ha a hallgatói normatívát (amely lényegében csak átfolyik az intézményi költségvetésen) nem vesszük figyelembe, akkor az alaptámogatás aránya átlagosan $33 \%$.
} 


\begin{tabular}{|c|c|c|c|c|c|c|c|c|c|}
\hline \multirow{2}{*}{ Intézmény megnevezése } & \multicolumn{5}{|c|}{ Hallgatók száma összesen } & \multicolumn{4}{|c|}{ Hallgatók számának változása } \\
\hline & 2006 & 2007 & 2008 & 2009 & 2010 & $2006->2007$ & $2007->2008$ & $2008->2009$ & $2009->2010$ \\
\hline Pannon Egyetem & 11419 & 11123 & 10478 & 10125 & 9632 & $-2,6 \%$ & $-5,8 \%$ & $-3,4 \%$ & $-4,9 \%$ \\
\hline Pécsi Tudományegyetem & 35117 & 33248 & 30620 & 29032 & 27963 & $-5,3 \%$ & $-7,9 \%$ & $-5,2 \%$ & $-3,7 \%$ \\
\hline Rendőrtiszti Főiskola & 1485 & 1496 & 1468 & 1520 & 1578 & $0,7 \%$ & $-1,9 \%$ & $3,5 \%$ & $3,8 \%$ \\
\hline Semmelweis Egyetem & 11143 & 10689 & 10602 & 11278 & 11898 & $-4,1 \%$ & $-0,8 \%$ & $6,4 \%$ & $5,5 \%$ \\
\hline Széchenyi István Egyetem & 12298 & 11095 & 10732 & 10786 & 11083 & $-9,8 \%$ & $-3,3 \%$ & $0,5 \%$ & $2,8 \%$ \\
\hline Szegedi Tudományegyetem & 30808 & 29721 & 28777 & 27436 & 27227 & $-3,5 \%$ & $-3,2 \%$ & $-4,7 \%$ & $-0,8 \%$ \\
\hline Szent István Egyetem & 14368 & 14591 & 13980 & $17464 * *$ & 16978 & $1,6 \%$ & $-4,2 \%$ & $24,9 \%$ & $-2,8 \%$ \\
\hline Színház-és Filmművészeti Egyetem & 305 & 280 & 328 & 268 & 276 & $-8,2 \%$ & $17,1 \%$ & $-18,3 \%$ & $3,0 \%$ \\
\hline Szolnoki Főiskola & 6213 & 5713 & 4769 & 4161 & 3356 & $-8,0 \%$ & $-16,5 \%$ & $-12,7 \%$ & $-19,3 \%$ \\
\hline Tessedik Sámuel Főiskola & 5732 & 4761 & 4241 & - & - & $-16,9 \%$ & $-10,9 \%$ & - & \\
\hline
\end{tabular}

Forrás: Oktatási Hivatal, felsőoktatási statisztikai adatok

zővé tette az állami intézmények számára (a nem állami intézményeknek csak lehetőségük volt erre), mégis felmerülhet a kérdés, hogy az intézmények vajon miért írták alá a szerződéseket? Miért nem lobbiztak a szerződések tartalmának módosításáért? Minthogy a tiltakozásnak nincsen nyoma, a feltételezésem az, hogy az intézmények bíztak abban, hogy a Minisztérium nem fogja komolyan venni a szerződések teljesítését. De vajon mire alapozhatták ezt?

A Mayer-féle modellt alapul véve azt feltételezhetjük, hogy a bizalom meglétének a magatartási következménye (a „kockázatvállalás a kapcsolatban” mező tartalma) a szerződés aláírása. Erre akkor kerül sor, ha nagyobb a bizalom, mint a szerződés aláírásának észlelt kockázata. Azt láttuk már, hogy a szerződés aláirásának egyes intézmények esetében jelentős volt a kockázata. Érdemes tehát megvizsgálni, hogy voltak-e olyan eszközök, amelyek a kockázatot csökkentették? Emellett azt is érdemes megvizsgálni, hogy hogyan alakult a Minisztérium bizalomra méltósága, azaz mi befolyásolhatta a Minisztérium képességének, jóindulatának és integritásának észlelését.

\section{Adatgyüjtés}

Az elemzés elvégzéséhez áttekintettem az intézményekkel kötött szerződéseket. Az EMMI és a Magyar Rektori Konferencia emellett hozzáférhetővé tett számomra számos dokumentumot is. Sajnos az intézmények által benyújtott beszámolókhoz nem jutottam hozzá.

Mindezek mellett négy olyan minisztériumi munkatárssal készítettem interjút, akik a hároméves fenntartói megállapodások rendszerének kialakításában részt vettek, vagy arra rálátással bírtak. Egy további interjút készítettem egy intézmény vezető tisztségviselöjével, aki a vezetöi pozíciót a konstrukció müködése alatt töltötte be. A 30-90 perces interjúkat 2015 és 2017 között készítettem. Az interjúkról egy kivételével nem készítettem felvételt. Ennek a téma érzékenysége volt az oka. Úgy véltem, hogy az interjúalanyok szabadabban fognak beszélni akkor, ha az interjúról csak jegyzetek készülnek. A jegyzeteket közvetlenül az interjúk után készítettem el.

\section{Főbb megállapítások}

\section{Az általános bizalom}

Noha nem áll rendelkezésre olyan felmérés, amely a hároméves fenntartói megállapodásban érintett szereplők általános bizalmáról adna tájékoztatást, iránymutatásul felhasználhatjuk a magyarországi értékszerkezetről készült felméréseket. A TÁRKI 2009-ben zajló adatfelvétele alapján Tóth István György például megállapítja, hogy ,,a magyar társadalom bizalomhiányos; nagyon kevéssé fogadja el az egyenlőtlenségeket; felemás viszonyban van a korrupt magatartás megítélését illetően; és alulértékeli az állami szolgáltatások adóárát, ezáltal magasabb elvárásokat fogalmaz meg az állammal szemben, mint amilyeneket az teljesíteni tudna" (Tóth, 2009, p. 15.). A bizalom általános szintjét mutatja, hogy a felmérésben a magyarok kétharmada úgy gondolja, hogy ö ugyan tisztességes, de a többiek nem.

Nem jobb a helyzet az intézményekkel szembeni bizalommal sem: miközben a magyar társadalom erősen államfüggő és paternalista, ,a magyarok kevéssé érzik magukénak az állami intézményeket, sokkal inkább továbbra is kijátszandó "ellenségként" kezelik (Tóth, 2009, p. 20.). Györffy ezt részben a szocialista rendszerre, részben pedig annak tovább élő örökségére vezeti vissza, aminek következményeként a rendszerváltó országokban ,a bizalmatlanság a rendszer alapvető jellemzője” (Györffy, 2014, p. 103.).

\section{A hároméves fenntartói megállapodások bevezetése}

Mint de Boer et al. (2015) összefoglalója alapján láthattuk, a teljesítményszerződések kialakítása meglehetősen komplex feladat, mert a megfelelő ösztönzők kialakítása igen nehéz. Ezzel szemben a hároméves fenntartói megállapodások előkészítése nagyon rövid idő alatt ment végbe, és a Minisztérium egyáltalán nem ragaszkodott az általa meghatározott indikátorok használatához.

Az egyik interjúalanyt a teljesítménymegállapodások rendszere a tervalkura emlékeztette, de két lényeges különbséget látott: egyrészt a tervalku része volt az, hogy a terveket a felettes szervvel (tervhivatallal, minisztériummal) megbeszélték, másrészt gyakorlat volt az is, hogy az azonos iparágban dolgozó szereplőket egy asztalhoz ültették, és ott mindenki előtt beszélték át velük a terveket, így a versenytársak is értesültek arról, hogy mit tervez a másik. Ezekről itt szó sem volt: az indikátorok kiválasztásáról, a mögöttes intézményi megfontolásokról, illetve az indikátorok célszerüségéről és mérhetőségéről nem volt egyeztetés a Minisztériummal. Ez a beszámolóknál sem volt jellemző: a Minisztérium ugyan készített értékelést a benyújtott beszámolókról, de ezek csak néhány tényszerü megállapításra szorítkoztak (például hogy hány indikátor 
értékében sikerült elérni az adott évre vonatkozó célértéket). Az intézményből érkező interjúalany úgy emlékezett, hogy a Minisztérium soha nem adott érdemi visszajelzést a beküldött anyagokra. Mindez azt sugallta, hogy a Minisztériumnak nincs szándéka vagy kapacitása a teljesítményszerződésekkel kapcsolatos teendők ellátására, vagy arra nem fordít komoly erőforrást. Azaz az intézmények e tapasztalatok alapján joggal vélhették úgy, hogy a Minisztérium nem képes, vagy nincs szándéka a szerződések betartását (azaz az indikátorértékeket) ellenőrizni.

A szerződésbe kerülő indikátorokat az intézmények maguk választhatták ki. Ez jelentős mértékben mérsékelte a szerződések nem teljesítéséből eredő kockázatokat. A Felsőoktatási és Tudományos Tanács (FTT) elvégezte a szerződésekben szereplő indikátorok részletes elemzését, amely alapján olyan megállapításokat tett, mint például "az intézmények olyan mutatókat választottak, amelyek könnyen és külön költség nélkül rendelkezésre állnak, könnyen számíthatók, és főképp mennyiségi mutatók" (FTT, 2008, p. 54.). Vagy: „A mutatók kiválasztását csaknem minden esetben - alapvetően egy kötelezettség minél egyszerübb teljesíthetőségének kritériuma motiválta." Hasonló megállapításra jutott az ÁSZ is, amikor úgy fogalmazott, hogy ,előfordultak nagyon könnyen teljesíthető indikátorok (például szabályzatok száma) vagy olyanok is, amelyek értékét az intézmény már a szerződés aláírásakor teljesítette" (ÁSZ, 2009, p. 57.).

A hároméves fenntartói megállapodásról szóló értékelések egy része (pl. ÁSZ, 2009; FTT, 2008) hangsúlyozta, hogy az indikátorok szabad megválasztása nem segíti az intézmények összehasonlítását. Mivel az intézmények az indikátorok mérésének mikéntjét is maguk határozták meg, ezért még az azonos indikátorokat használó intézmények esetében sem biztosítható az összehasonlítás. Ez akkor jelentett volna igazán problémát, ha a Minisztérium az intézmények közötti versenyt akarta volna élénkíteni. Az összehasonlítás mellőzése azonban a Minisztérium részéről szándékolt megközelítés volt. Az intézményeknek írt 27482-3/2007 számú körlevélben az államtitkár például úgy fogalmazott, hogy a ,,megválasztott teljesítménymutatók nem a felsőoktatási intézmények közötti összehasonlítást szolgálják, hanem az intézmény által megfogalmazott fejlesztési stratégiája számszerüsíthető mutatói alapján ad lehetőséget az időközi ellenőrzésre és a három éves ciklus zártával az intézményi teljesítés minősítésére." Azaz az indikátorok sokkal inkább fejlesztési, mint kontrolleszközként fogalmazódnak meg, amikor az intézmény saját magához mért előrehaladását szolgálja. A hároméves fenntartói megállapodások rendszerének első változatát bemutató anyagban pedig a következő megállapítás szerepel: „A hároméves megállapodásokkal a differenciálódott, eltérő minőségű intézmények mindegyikénél saját teljesítményük növelésének elérése a cél, s ennek során kívánatos, ha erre erösségeik mentén kerül sor. Ez pedig azt jelenti, hogy nem a horizontális, hanem a vertikális, azaz adott intézmény teljesítménye időbeli összevethetőségét kell biztosítani" (OKM, 2007a, p. 2.).

Ez az intézményekkel szemben sokkal toleránsabb, jóindulatúbb megközelítés, mint egy versengést erősíte- ni kívánó attitűd. Erre utal az FTT 2008-as elemzésében szereplő kissé feddő megjegyzés is, amely szerint „,az alkalmazott eljárás gyenge pontja (...) [az] erős intézményi pozícióban és a Minisztérium ezzel kapcsolatos megengedő magatartásában keresendő" (FTT, 2008, p. 22.).

$\mathrm{Az}$ indikátorok megválasztásában ez a megengedő magatartás több tényezőhöz is kapcsolható. De Boer et al. (2015) Seneca híres mondását idézve - „Aki nem tudja, melyik kikötőbe tart, annak mindegy, hogy merről fúj a szél" - hangsúlyozza, hogy a teljesítménymegállapodásoknak nem szabad öncélúnak lenniük. Ugyanakkor az indikátorok megválasztása során nem volt olyan nyilvános stratégia, amelynek megvalósítását a hároméves fenntartói megállapodással szolgálni akarták: ,a magyar felsőoktatás stratégiai irányait, céljait, eszközrendszerét és a kívánt célállapot jellemzőit konkrétan tartalmazó törvény, országgyülési határozat, kormányrendelet vagy határozat, miniszteri rendelet nem készült (...)" (ÁSZ, 2009, p. 58.). Így nem volt olyan ágazati célokat leíró dokumentum sem, amely az intézmények számára az indikátorok megválasztása során irányadó lett volna. 2010-ben, a záró beszámolók leadását követően a Minisztérium a következő időszakra vonatkozó célkitűzéseket is megkérte az intézményektől. Ám az intézmények egy része - ahogyan az a Minisztérium belső feljegyzéséből kiderül - ,„a saját [stratégia hiánya miatt], néhányan a felsőoktatási stratégia hiánya miatt utasították el a teljesítménycélok, illetve az ehhez tartozó értékek megadását" (OKM, 2010, p. 2.).

A megengedő felfogásban szerepet játszhatott az is, hogy - miként arra több interjúalany is utalt - a fenntartói megállapodások ötlete nem a Minisztériumból származott, hanem az egyik kormánypárt oktatási kabinetjéből. Így feltételezhetjük, hogy a felsőoktatási terület vezetése nem volt olyan elkötelezett az elképzelés megvalósítása iránt, mert nem érezte annyira sajátjának az elképzelést, így csak inkább megvalósítóként lépett be a folyamatba. $\mathrm{E}$ feltételezést az interjúk alapján nem sikerült sem cáfolni, sem megerösíteni.

Végezetül fontos lehet az is, hogy a Minisztérium egyik felsőoktatással foglalkozó vezetője (aki egyébként maga is a felsőoktatásból érkezett) a Minisztérium szerepét inkább problémamegoldóként értelmezte, amely segítséget nyújt az intézmények által felvetett nehézségek megoldásában. Ebben közrejátszott az is, hogy a rektorokkal közvetlen volt a Minisztérium kapcsolata, és rendszeresen bejártak megbeszélni a folyó ügyeket. A Minisztérium szerepe eszerint tehát sokkal inkább az intézmények támogatása, valamint az intézményi és az ágazati érdekek képviselete volt, és nem a kormányzati érdekek intézményekkel szembeni érvényesítése. Mindezek az OKM jóindulatú, együttműködő hozzáállását tükrözték az intézmények számára.

Ennek látszólag ellentmondanak maguk a szerződések. A szerződéses viszony a felek egyenrangúságát sugallta, ami jól illett a felsőoktatási intézmények autonómiájához. Ezt tovább erősítette az, hogy a szerződésbe belefoglalták: a teljesítés elismerésének vitatása esetén bármelyik fél a bírósághoz fordulhat, elvben tehát az intézmény is perelhette volna a Minisztériumot. Valójában a szerződések meglehe- 
tősen aszimmetrikusak voltak: a megállapodások megkötése az állami intézmények számára kötelező volt, és az csak az intézmények nem-teljesítésének eseteit és szankcióit részletezte, a Minisztérium nem teljesítésének lehetőségeit nem.

Mint azonban korábban láttuk, a Minisztérium magatartása igen megengedő volt, aminek az lehetett az egyik oka, hogy a felek között nem voltak súlyos érdekkonfliktusok. Sőt inkább érdekazonosság volt, ami egyfelöl a minél jobb ágazati költségvetési pozíció kiharcolását, másrészt az esetleges botrányok elkerülését jelentette (ne feledjük, a 2008-as népszavazások elött történt meg a szerződések aláírása).

A szerződések tehát bár látszólag előnytelenek voltak az intézmények számára, nem ütköztek a Magyar Rektori Konferencia komoly ellenállásába sem, amelynek - amint arra az egyik interjúalany utalt - nem volt ellenére a megállapodások megkötése. Ennek oka több interjúalany szerint is az volt, hogy a szerződések szerepe nem az intézmények kényszerítése volt, hanem olyan eszközök létrehozása, amelyeket a Minisztérium sikerrel használhat a Pénzügyminisztériummal (PÜM) szembeni érvelésben. Egyfelől a beszámolók láthatóbbá tették a PÜM számára kevéssé transzparens felsőoktatási ágazat aktivitását, amely addig leginkább csak a hallgatói létszámokat látta (és finanszírozta). Így viszont láthatóvá lehetett más tevékenységeket is tenni (pl. a nemzetköziesítést). Másrészt a szerződéses jelleg, illetve a bírósági kikényszeríthetőség beépítése is inkább a Pénzügyminisztériummal szembeni érvelésben játszhatott szerepet, mert érveket adott azok ellen a kezdeményezések ellen, amelyek a felsőoktatás állami támogatásának csökkentésére irányultak. A szerződéses kötelem érve vélhetően erősebb lehetett volna, ha a bírósági kikényszeríthetőség az állami támogatások kifizetésére is explicitebb módon vonatkozott volna, de ekkor a kitalált konstrukció nem biztos, hogy átment volna az államigazgatási egyeztetéseken.

Az OKM valódi kötelezettségeket a szerződések ellenére sem tudott vállalni, mert ehhez többéves költségvetésre lett volna szükség. (Ez magyarázza a szerződésekben szereplő kötelezettségek egyoldalúságát is.) Ez bebizonyosodott akkor, amikor a 2008-as gazdasági válságot követően megkezdődött a felsőoktatási források zárolása. Ez jól tükröződik a 2. táblázatban látható összesítésböl, amelyben látható, hogy semmi nem lett a felsőoktatás állami támogatásának növelésére vonatkozó, 2007-ben kihirdetett szándékából.

2. táblázat A felsőoktatás állami támogatásának alakulása 2007 és 2011 között (Mrd Ft)

\begin{tabular}{|l|l|l|l|l|l|}
\hline Cím & 2007 & 2008 & 2009 & 2010 & 2011 \\
\hline $\begin{array}{l}\text { Támogatás az "Egyetemek, } \\
\text { Főiskolák" címen }\end{array}$ & 184,2 & 191,1 & 185,6 & 180,7 & 170,4 \\
\hline $\begin{array}{l}\text { HM-BM, illetve KIM feje- } \\
\text { zet felsőoktatási intézmé- } \\
\text { nyeinek támogatása }\end{array}$ & 6,7 & 6,1 & 4,8 & 5 & 4,7 \\
\hline $\begin{array}{l}\text { Fejezeti kezelésủ támoga- } \\
\text { tások (benne a nem állami } \\
\text { felsőoktatással) }\end{array}$ & 16,1 & 16,5 & 16,5 & 18,6 & 15,3 \\
\hline ebből PPP & 3,0 & 5,8 & 6,9 & 9,3 & 9,3 \\
\hline $\begin{array}{l}\text { Felsőoktatási müködési } \\
\text { támogatás mindösszesen }\end{array}$ & 207,0 & 213,7 & 206,9 & 204,3 & 190,4 \\
\hline
\end{tabular}

Forrás: Polónyi (idézi Berács et al., 2014)
Az állami támogatások csökkenése természetesen az egész szerződéses konstrukció legitimitását is aláásta, és rontotta a Minisztérium bizalomra méltóságának megítélését az intézmények körében. Ha ugyanis a Minisztérium nem tudja garantálni az alaptámogatás stabilitását, akkor vajon jogosan várja el az intézményektől a teljesítést? Bár a szerződések aláíráskor ez még nem volt tudható, e fejlemények azt valószínüsítették, hogy a Minisztérium a teljesítések ellenőrzése során nem fog élni a szerződésben szereplő szankciókkal.

A lefolytatott interjúk során a hároméves fenntartói megállapodások elindítására további (kiegészítő) magyarázatok is elhangoztak.

Ezek egyike az volt, hogy az intézmények növekvő teljesítményét a rektorok közelmúltban megemelt bérének igazolásaként akarták felhasználni. Az intézményi beszámolókat a külső tagokból álló gazdasági tanácsnak is el kellett fogadnia, ami tovább erősítette a béremelés indokoltságát. Egyes intézményekben a rektor jutalmát is a beszámoló elfogadásához és arányos teljesítéséhez kapcsolták.

Egy másik magyarázat szerint a hároméves fenntartói megállapodások rendszerének bevezetése intézményes jogalapot teremtett olyan kifizetésekre, amelyekre a normatív támogatás keretei között kevesebb lehetőség lett volna. A teljesítménymegállapodások így tehát lényegében csökkentették a képlet szerinti (normatív) finanszírozás automatizmusait, és könnyebben befolyásolhatóvá tették az intézményi költségvetéseket. Ezt engedi sejtetni például az a tény, hogy az egyik erős kormányzati kapcsolatokkal bíró intézmény szerződéséhez az aláírással egyidejüleg kiegészítő megállapodást füztek, amely szerint a Minisztérium 200 millió forint többlettámogatást biztosít az intézmény számára, és garantálja, hogy ez a többi évben is az alaptámogatás része lesz.

Bár az interjúk ezt nem támasztották közvetlenül alá, érdemes megemlíteni Polónyi (2010) olvasatát is, aki szerint a rendszer bevezetésének oka az volt, hogy mind a felsőoktatási kormányzat, mind pedig az intézmények érdekeltek voltak a cselekvés látszatának fenntartásában. A kormányzat proaktív, kezdeményező képet akar magáról kialakítani, az intézmények pedig a mindenek feletti autonómiájukat akarják megőrizni, és ehhez közös látszatcselekvésre van szükség. Ez összhangban van az érdekek egyezésével kapcsolatos korábbi állítással is.

\section{Összefoglaló megállapítások}

A tanulmány elején feltett kérdés arra vonatkozott, hogy vajon hogyan befolyásolja a közpolitikai kezdeményezések implementációját, illetve annak sikerességét a folyamatban részt vevő szereplök egymás iránti bizalma. Miért bíztak az intézmények abban, hogy a Minisztérium nem fogja a szerződésben vállalt szankciókat érvényesíteni, miközben azok bekövetkezése valószínűsíthető volt? Milyen alapon bíztak az intézmények a Minisztériumban? A kérdésre Mayer et al. (1995) modellje és más, bizalommal kapcsolatos szakirodalom alapján választ lehet adni.

A modell szerint a szerződés aláírása vagy megváltoztatása függ a kockázat nagyságától és a bizalom szintjétől.

Az intézmények az indikátorok „megfelelő” (könynyen teljesíthető) megválasztásával sokat tudtak tenni a 
kockázatok csökkentése érdekében, amivel csökkent a Minisztériummal szembeni sebezhetőségük. A szerződésben szereplő hallgatói létszámok csökkenésével kapcsolatos szankciókra viszont ez nem adhatott megnyugtató választ, tehát a minisztériummal kapcsolatos bizalom is szerepet játszhatott.

Annak ellenére, hogy a magyar társadalomban az általánosított bizalom szintje alacsony, a Minisztérium számos módon erősítette az intézményekben a bizalomra méltóságának megítélését.

Az elemzési modell szerint a bizalomra méltóság függ a bizalmat kapó jóindulatától (mennyire veszi figyelembe a másik érdekeit), a képességétől (képes-e betartani, amit ígér), és integritásától (értékek, elvek azonossága, következetessége).

Ezek intézményi megítélését a hároméves megállapodásokon kívüli tapasztalatok is befolyásolhatták, de a konkrét szerződéses konstrukcióból is számos következtetése vonható le (lásd a 3. táblázatot).

A Minisztérium jóindulatot demonstrált az intézményekkel szemben, azaz igyekezett az intézményi érdekeket minél jobban figyelembe venni a konstrukció kialakítása során: alapvetően szolgáltató és az intézményekért lobbizó megközelítés jellemezte a müködést, a konkrét koncepció kialakításába pedig igyekezett bevonni az intézményeket, véleményüket figyelembe vette, és a javaslatot felpuhította (például az indikátorok megválasztása során). Az érdekek azonosságát jelezte, hogy sem a Minisztérium, sem az intézmény nem volt érdekelt abban, hogy a szerződés érvényesítésével botrány kerekedjen. Ez lehetővé tette a kalkulatív bizalom kialakulását is, azaz azt a helyzetet, amikor egyik félnek sem érdeke a másik sebezhetőségének kihasználása.

A Minisztérium ráutaló magatartásával évről évre azt is jelezte, hogy nincs képessége/kapacitása/szándéka az intézmények és a leadott beszámolók ellenőrzésére, nyomon követésére, hiszen az intézmények a három év alatt nem találkoztak a beszámolóik mélyebb értékelésével. Ez egyben a folyamatalapú bizalom kialakulását is elősegítette.

Az integritást és az identifikáción alapuló bizalmat az szavatolta, hogy Minisztérium ágazati vezetőinek egy része maga is a felsőoktatásból érkezett (3. táblázat).

3. táblázat A Mayer et al. (1995) modell tényezőinek értelmezése a hároméves fenntartói megállapodások kapcsán

\begin{tabular}{|c|c|}
\hline Tényezỏ a Mayer et al. modellben & A tényezỏó értelmezése a konkrét esetben \\
\hline Bizalom & $\begin{array}{l}\text { Az intézmény várakozása, hogy Ministérium a szerzzódést nem fogja betartani, } \\
\text { betartatni. Az intézmény felvállalja ennek nem teljesullése esetén bekövetkezó } \\
\text { scberhetốśget. }\end{array}$ \\
\hline Kockázatvállalás a kapcsolatban & $\begin{array}{l}\text { A szerźdés megkötése annak ellenére, hogy ha a Minisztérium azt komolyan veszi, } \\
\text { akkor az kedvezótlen lesz az intézmény számára. }\end{array}$ \\
\hline Képesség & $\begin{array}{l}\text { A Minisztériumnak nincs képessége/kapacitása/szándéka a szerződések ellenórzésére, } \\
\text { betartatására. }\end{array}$ \\
\hline Jóindulat & 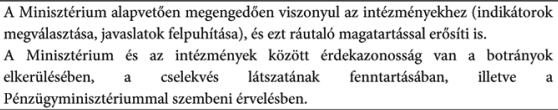 \\
\hline egrn & $s$ munkatársai maguk is a felső \\
\hline
\end{tabular}

Forrás: saját szerkesztés

Fontos tisztázni a kutatás korlátait is. Egyrészt nem vizsgáltam a Minisztérium és az intézmények közötti kapcsolat történetiségét. A bizalom a Minisztériummal kapcsolatos korábbi tapasztalatokból is fakadhatott.

Másrészt most csak azt vizsgáltam, hogy hogyan ala- kult az OKM iránti bizalom intézményi nézőpontból. Az elemzés mások nézőpontjából is elvégezhető lett volna. Például milyen volt az intézmények bizalomra méltóságának a megítélése a Minisztériumban? Hogyan befolyásolta a fenntartói megállapodások bevezetése az OKM megítélését a Pénzügyminisztériumban? Mennyiben tünhetett az OKM képesnek, jóindulatúnak és integráltnak a PÜM képviselőinek szemében? És a közvélemény szemében?

Harmadrészt fontos azt is látni, hogy a jelen kutatás inkább a Minisztérium magatartásának elemzésére épült, és kevésbé a magatartás intézményi észlelésének elemzésére. Ehhez a jelenleginél jóval több intézményvezetői interjúra lenne szükség.

Érdemes megvizsgálni a hároméves fenntartói megállapodások rendszerét a teljesítménymegállapodásokkal kapcsolatos ajánlások tükrében is.

A magyar felsőoktatás - miként az intézmények gazdasági-pénzügyi tevékenységét felügyelő testületek (boardok) bevezetési próbálkozása során is - a teljesítménymegállapodások esetében is a korai adoptálók között szerepelt megelőzve számos más fejlett országot. A fenntartói megállapodások rendszere az első komoly kísérletnek tünik a szakmai indikátorok átfogó, irányítási célú használatára a magyar felsőoktatásban. Az eredmény azonban felemás. A hároméves fenntartói megállapodások rendszere az ambiciózusabb intézményvezetők számára jó apropót tudott teremteni belső indikátorrendszerek kialakítására és elfogadtatására. Egyes intézményekben ezt még karokra is tovább bontották, így megfelelő vezetői elkötelezettség esetén egy belső értékelési rendszer alapjává is válhatott. Ez azonban nem a kialakított rendszer érdeme, hanem inkább az intézményé.

A rendszer összességében inkább egy bürokratikus eljárás lett formális megfelelésekkel, mintsem valódi stratégiai irányítási eszköz. Ebben szerepet játszott, hogy a rendszert súlyos konstrukciós hibákkal tervezték meg.

$\mathrm{Az}$ indikátorok teljesen szabad megválasztása rendkívül problémás. Ez eredetileg nem is így szerepelt a tervekben, csak később lazult fel ennyire az elképzelés. Önmagában nem elképzelhetetlen, hogy az intézményekre bízzuk az indikátorok megválasztását, hogy az az intézményi preferenciákat tükrözze. De ebben az esetben is lehetett volna ennél tartalmasabb, mérhetőbb és ellenőrizhetőbb indikátorokat találni. A rendszer eröltetett ütemü bevezetése ezt a folyamatot nem tette lehetővé. Egy ágazati stratégia jelenléte is orientáló lett volna az indikátorok megválasztása és jóváhagyása során.

A Minisztérium sem a bevezetéskor, sem a későbbiekben nem használta ki a teljesítménymegállapodásokat az intézménnyel folytatott stratégiai dialógusra. Ez kihagyott lehetőség volt. Ennek persze nemcsak képességbeli/ kapacitásbeli okai lehettek, hanem az is, hogy egy olyan országban, ahol az intézményeket nem is olyan régen még többé-kevésbé közvetlenül irányították, a „karnyújtásnyi” távolság veszélyes közelségnek tünhet, amit jobb elkerülni mind a beavatkozás látszatát kerülni akaró minisztérium, mind az autonómiáját féltő intézmény számára. Jól látszódott ez például a 2012-es intézményfejlesztési tervek kialakítása során. A Nemzeti Erőforrás Minisztérium (NEFMI) igyekezett aktív konzultációt folytatni az intéz- 
ményekkel, amelyek azonban sokszor nem tudták eldönteni, hogy a konzultáción elhangzott felvetéseket (például a NEFMI integrációra vonatkozó elképzeléseit) be kell-e építeniük az IFT-be mint „,visszautasíthatatlan kérést”, vagy pedig - ha azzal nem értenek egyet - van lehetőségük azt figyelmen kívül hagyni.

A túlságosan gyors, sok szempontból elhibázott és félszívvel megvalósított bevezetés nemcsak felesleges erőforrásokat kötött le, hanem hosszabb időre hiteltelenítette is a teljesítménymegállapodások eszközét. Ugyanakkor az is igaz, hogy a gazdasági válság igen kedvezőtlen helyzetet teremtett a teljesítménymegállapodások rendszerének müködtetésére. Ennek ellenére úgy vélem, hogy a bevezetés alaposabb és a szereplőknek időt adó előkészítése, a megállapodások kiérlelése, a rendszeres és érdemi visszacsatolásokra időt és erőforrást szánó megközelítés, az ágazati célrendszer megfogalmazása és a megállapodások transzparenciája sikeresebbé tudta volna tenni a reformot a kedvezőtlen kontextus ellenére is.

Az elemzett példa arra mutat rá, hogy a szereplők közötti bizalom hogyan teszi lehetővé a reformok elszabotálását. Ez azonban nem szükségszerü. A teljesítményszerződések komolyabban vétele nem zárja ki sem a minisztérium jóindulatú és hozzáértő hozzáállását, sem integritását. Ezért lehetségesnek és kívánatosnak vélem, hogy a szereplök közötti bizalom ne a teljesítményszerződések céljai ellen, hanem azokkal összhangban müködjön.

\section{Felhasznált irodalom}

ÁSZ (2009). Jelentés a felsőoktatási törvény végrehajtásának ellenőrzéséről. Budapest: Állami Számvevőszék.

Barakonyi, K. (2009). Megtorpant intézményirányítási reform. Új Pedagógia Szemle, 59(12), 3-42. Elérhetö: http://epa.oszk.hu/00000/00035/00138/pdf/ EPA00035_upsz_200912_001-042.pdf

Berács J., Kováts G., Hrubos I., \& Temesi J. (2014). Magyar Felsőoktatás 2013. Stratégiai helyzetértékelés. Budapest: Nemzetközi Felsőoktatási Kutatások Központja. Elérhető: http://nfkk.uni-corvinus.hu/index.php?id=55712

de Boer, H., Jongbloed, B., Benneworth, P., Cremonini, L., Kolster, R., Kottmann, A., Lemmens-Krug, K., \& Vossensteyn, H. (2015). Performance-based funding and performance agreements in fourteen higher education systems. Report for the Ministry of Education, Culture and Science. Twente, Netherland: Center for Higher Education Policy Studies.University of Twente.

de Boer, H., Jongbloed, B., Enders, J., \& File, J. (2010). Progress in higher education reform across EuropeGovernance reform. Twente, Netherland: Centre for Higher Education Policy Studies, Universtiy of Twente.

Derényi, A. (2009). A magyar felsőoktatás átalakulása 1989 és 2008 között. In Drótos, Gy. \& Kováts, G. (szerk.) (2009), Felsőoktatás-menedzsment (pp. 31-62). Budapest: Aula Kiadó.

Estermann, T. \& Nokkala, T. (2009). University autonomy in Europe I. Brussels, Belgium: European University Association.

Estermann, T., Nokkala, T., \& Steinel, M. (2011). University autonomy in Europe II. The scorecard. Brussels, Belgium: European University Association.
Fielden, J. (2008). Global trends in university governance. The Education Working Paper Series 9. Washington, DC: World Bank.

FTT (2008). Az OKM és az állami felsőoktatási intézmények között létrejött három éves (2007-2010) fenntartói megállapodásokban szereplö teljesitménymutatók elemzése és értékelése. Jelentés II. rész. Budapest, Magyarország: Finanszírozási és Tudományos Tanács.

Györffy, D. (2014). Bizalom és gazdaságpolitika: fejezetek az euró történetéből. MTA doktori értekezés. Budapest, Magyarország: Magyar Tudományos Akadémia. Elérhető: http://real-d.mtak.hu/684/

Hajnal, Gy. (2012). Hungary. In Verhoest, K., Van Thiel, S., Bouckaert, G., \& Lægreid, P. (Eds), Government Agencies: Practices and Lessons from 30 Countries (pp. 288-299). Basingstoke, UK: Macmillan.

Halász G. (2012). Finanszírozási reformok a felsőoktatásban: nemzetközi összehasonlító elemzés. In Temesi J. (szerk.), Felsöoktatás-finanszírozás: nemzetközi trendek és hazai gyakorlatok (pp. 11-66). Budapest: Aula Kiadó.

Hardin, R. (2006). Trust. Cambridge, UK: Polity Press.

Hurley, R. F. (2012). The decision to trust: How leaders create high-trust organizations. San Francisco, CA: JosseyBass.

Jongbloed, B., Kaiser, F., van Vught, F., \& Westerhejide, D. (2018). Performance agreements in higher education: A new approach to higher education funding. In Curaj, A., Deca, L., \& Pricopie, R. (Eds.), European Higher Education Area: The Impact of Past and Future Policies (pp. 671-688). Cham, Switzerland: Springer. http://doi.org/10.1007/978-3-319-77407-7_40

Jongbloed, B., De Boer, H., Enders, J., \& File, J. (2010). Progress in higher education reform across EuropeFunding reform. Twente, Netherland: Centre for Higher Education Policy Studies.

Keczer, G. (2016). Variációk egy témára - az állami kontroll eszközei a felsőoktatásban. In Kováts G.(szerk.), $A$ kancellári rendszer bevezetése a magyar felsőoktatásban: Tapasztalatok és várakozások (pp. 58-84). Budapest, Magyarország: NFKK.

Kováts, G., Heidrich, B., \& Chandler, N. (2017). The pendulum strikes back?: An analysis of the evolution of Hungarian higher education governance and organisational structures since the 1980s. European Educational Research Journal, 6(5), 568-587. http://doi. org/10.1177/1474904117697716

Kováts, G., Nagy, S. Gy., \& Németh, A. O. (2012). Felsőoktatás-irányítás és -finanszírozás: Nemzetközi trendek és jó gyakorlatok. Felsőoktatási Mühely, 5(1)

Lewicki, R. \& Bunker, B. (1996). Developing and maintaining trust in work relationships. In Kremer, R. \& Tyler, T. (Eds.), Trust in Organizations: Frontiers of Theory and Research (pp. 114-139). Thousand Oaks, CA: Sage. http://doi.org/10.4135/9781452243610.n7

Mayer, R. C., Davis, J. H., \& Schoorman, F. D. (1995). An integrative model of organizational trust. The Academy of Management Review, 20(3), 709-734. http://dx.doi. org/10.2307/258792 
Möllering, G. (2001). The nature of trust: From Georg Simmel to a theory of expectation, interpretation and suspension. Sociology, 35(2), 403-420. http://doi. org/10.1017/S0038038501000190

OKM (2007). Az állami felsőoktatási intézményekkel kötendő hároméves fenntartói finanszírozási megállapodásról. 2007. április 17.

OKM (2010). Összefoglaló a hároméves fenntartói megállapodás (2008-2010) teljesítéséről (az előzetes záró beszámolók alapján). 2010. szeptember 29.

Osborne, D. \& Hutchinson, P. (2012). A kormányzás ára: Hatékonyabb közszolgáltatások megszoritások idején. Budapest, Magyarország: Alinea Kiadó.

Polónyi, I. (2010). Hoztak is, meg nem is. Educatio, 19(1), 111-126.

Pruvot, E. B., \& Estermann, T. (2017). University autonomy in Europe III. The scorecard 2017. Brussels, Belgium: European University Assocations.

Rommel, J., \& Christiaens, J. (2009). Steering from ministers and departments: Coping strategies of agencies in Flanders. Public Management Review, 11(1), 79-100. http://doi.org/10.1080/14719030802493569

Rousseau, D. M., Sitkin, S. B., Burt, R. S., \& Camerer, C. (1998). Not so different after all: a cross-discipline view of trust. Academy of Management Review, 23(3), 393-404. http://doi.org/10.5465/amr.1998.926617

Schoorman, F. D., Wood, M. M., \& Breuer, C. (2015). Would trust by any other name smell as sweet?: Reflections on the meanings and uses of trust across disciplines and context. In Bornstein, B. H., \& Tomkins, A.
J. (Eds.), Motivating cooperation and compliance with authority: The role of institutional trust (pp. 13-36). Cham, Switzerland: Springer.

Schoorman, F. D., Mayer, R. C., \& Davis, J. H. (2007). An integrative model of organizational trust: Past, present, and future. Academy of Management Review, 32(2), 344-354. http://doi.org/10.5465/ amr.2007.24348410

Tóth, I. GY. (2009). Bizalomhiány, normazavarok, igazságtalanságérzet és paternalizmus a magyar társadalom értékszerkezetében. A Gazdasági felemelkedés társadalmi-kulturális feltételei címü kutatás zárójelentése. Budapest, Magyarország: TÁRKI.

van Thiel, S. (2012). Comparing agencies across countries. In Verhoest, K., Van Thiel, S., Bouckaert, G., \& Lægreid, P. (Eds.), Government agencies. practices and lessons from 30 countries (pp. 18-26.). Basingstoke, UK: Macmillan.

Verhoest, K., Van Thiel, S., Bouckaert, G., \& Lægreid, P. (2012). Introduction. In Verhoest, K., Van Thiel, S., Bouckaert, G.,\& Lægreid, P. (Eds.), Government agencies: Practices and lessons from 30 countries (pp. 3-17). Basingstoke, UK: Macmillan.

Verhoest, K. (2018). Agencification in Europe. In Ongaro, E., \& van Thiel, S. (Eds.), The Palgrave handbook of public administration and management in Europe (pp. 327-346). Basingstoke, UK: Macmillan.

Williamson, O. (1993). Calculativeness, trust, and economic organization. The Journal of Law \& Economics, 36(1), 453-486. http://www.doi.org/10.1086/467284 